\title{
Generative Grammar in Albanian Linguistics
}

\author{
Eljana Mosko \\ "Eqrem Çabej" University of Gjirokastra \\ Email: emosko@uogj.edu.al
}

\section{Doi:10.5901/mjss.2014.v5n20p2387}

\begin{abstract}
Generative grammar was not part of Albanian linguistics until the beginning of the XXI century when it became the object of study in the works of some Albanian linguists. Research is focused in the three aspects of generativism - what constitutes the knowledge of language, how the knowledge is acquired and how the knowledge is put to use. Most part of the research focuses on syntax with regard to rules that will correctly predict which combinations of words will form grammatical sentences. Research is done in language acquisition as well (with regard to acquiring of Albanian language), which in a way or another fulfills the three aspects of generativism. The studies and the research are associated with the tradition of grammatical research initiated and inspired by the work of Noam Chomsky.
\end{abstract}

Keywords: generativism; grammar; Albanian linguistics; phrase; traditional grammar, Chomsky

\section{Introduction}

The term "generative" is associated with the tradition of grammatical research initiated and inspired by the work of Noam Chomsky. This term is sometimes construed very narrowly to refer only to work directly derivative from Chomsky's (Wasow, 2003). Here it will be used more broadly to refer to work generally within the Chomskian tradition, irrespective of whether its formalism and terminology come directly from Chomsky.

One of the basic theories of generative grammar is Universal Grammar. As Radford (2004:8) puts it there are a number of criteria of adequacy which a theory of Universal Grammar must satisfy. One such criterion (which is implicit in the use of the term Universal Grammar) is universality, in the sense that a theory of UG must supply us with the tools needed to provide a descriptively adequate grammar for any and every human I-language (i.e. a grammar which correctly describes how to form and interpret expressions in all languages).

These studies gave rise to Albanian generative grammar, an unfilled gap, until the beginning of the XXI century when the first works were undertaken by Albanian generativists. There started a new era in Albanian linguistics, which challenged in a way the traditional grammar.

\section{The Phrase and the Constituent Grammar in Albanian Generative Linguistics}

Generative grammar was not part of Albanian linguistics until the beginning of the XXI century when it became the object of study in the works of some Albanian linguists such as: L. Buxheli, Th. Dhima, R. Memushaj, D. Kallulli, J. Mita, S. Ahmetaj, E. Kapia etc. They adopted the Chomskian theory in studying linguistics and contributed to the development of Albanian generative grammar. Research is done in the three aspects of generativism - what constitutes the knowledge of language, how the knowledge is acquired and how the knowledge is put to use.

Most part of the research focuses on syntax with regard to rules that will correctly predict which combinations of words will form grammatical sentences, respectively introducing into Albanian linguistics the generative grammar terminology such as hierarchical structure, constituent, phrase structure, argument, adjunct, coordination, X-bar, headinitial, deep and surface structure etc.

According to Hyska (2009: 27) if we refer to the term "phrase" (among all regarding it, like noun phrase, verb phrase, inflection phrase, phrase structure etc.) there are records that as a term it was firstly introduced in the Albanian linguistics by S. Prifti since 1957 in the article "The seeds of syntactic units" (Farët e njësive sintaksore). The term phrase is also found in the works of $\mathrm{E}$. Çabej and $\mathrm{H}$. Agani referring to the article "On questionable issues of the theory of word grouping" (Ç'shoh të diskutueshme në teorinë e togfjalëshit). Nevertheless, the term phrase used by these authors does not comply with the generative meaning and the context used in the syntax of the generative grammar. 
The introduction of Albanian grammar (to my knowledge) into the generative frame was done by Philip L. Hubbard's article on "Dative Clitics in Albanian: Evidence for Syntactic Levels" (1981: 83), who utilizing the relational grammar framework outlined in Perlmutter and Postal (1977), undertook research with regard to indirect object and its relation with the dative clitic in albanian.

A significant step in the studies of Albanian generative grammar was taken by D. Kallulli $(1995,1999,2000)$ with the articles "Clitics in Albanian", "The Comparative Syntax of Albanian: On the Contribution of Syntactic Types to Propositional Interpretation" and "Direct Object Clitic Doubling in Albanian and Greek" (among other works), where the phrase - the clitic phrase (CIP), the determinative phrase (DP) etc. of Albanian - is part of the comparative syntactic analysis in the frame of generative grammar.

The term phrase is also found in the article of S. Ahmetaj $(2000 ; 5)$ with regard to definition of the sentence; according to her "the sentence consists of constituents which in generative grammar are called the noun phrase (NP) and verb phrase (VP).

Nevertheless, the research was mainly introduced in international conferences and articles in international journals, and as a result the terms generativism and generative grammar were not included in the texts of the students who studied linguistics in Bachelor level. The university texts (2002) were mainly based on traditional grammar with reference to word grouping theory and there lacked the latest trends in linguistics referring to the Chomskian tradition of generative grammar.

The term phrase was firstly introduced to the university level in the text "Introduction to linguistics" (Hyrje në gjuhësi) of R. Memushaj (2002), where the phrase is characterized as a constituent, part of a sentence, a unit of hierarchic structure, the kinds of phrases, introduced in the frame of X-bar theory, their nature of formal and semantic approaches etc.

Hyska (2009: 28) underlines the fact that the term phrase (sintagma), in the over mentioned study, is compared to the term word grouping (togfjalësh), by bringing arguments of its advantages over the latter with reference to linguistic analyses. The structural analysis using the phrase is an all inclusive analysis which challenges the traditional analysis of word grouping, with regard to subcategorisation, constituent and semantic structure, which are not part of the traditional theory of word grouping.

The concept of phrase structure is taken even further in the first edition of R. Memushaj monograph "Generative linguistics" (Gjuhësia gjenerative) (2008). The monograph highlights not only the structure and its characteristics, but also the phrase in the generative theory and its development from its introduction to Chomsky's minimalist program.

The research done by R. Memushaj was deepened by F. Koleci and G. Turano in the book "Introduction to the generative syntax of Albanian" (Hyrje në sintaksën gjenerative të shqipes) (2011). The book introduces the basic components of Chomsky's generative theory with the respective analysis in Albanian. It shows how basic grammatical concepts of Albanian are incorporated into general principles of generative grammar, including the relationships between phrasal categories, the integration of transformations, levels of syntactic representation etc.

The monograph of J. Mita "Introduction to the generative syntax" (Hyrje në sintaksën gjenerative) (2005) is also to be mentioned with reference to the phrase as a unit that stands between the constituent and the sentence. It provides the reader with knowledge of the philosophy and methods of generative grammar starting with Chomsky's cognitive approach to the study of the language emphasizing that the grammatical knowledge of how we interpret expressions in the native language is tacit (i.e. subconscious) rather than explicit (i.e. conscious). Mita (2005: 14) states that "each of us can distinguish the phrases in the native language, but the respective knowledge is subconscious and silent". It provides a practical and thorough review of the constituents that form the phrase and what are the criteria to be met in order to call these units as phrases.

The term and the concept "phrase" is also found in the syntactic analysis of Th. Dhima in the book "Albanian language - the syntax" (Gjuha shqipe - sintaksa) (2005). In the text the reader is able to translate analyses from the general generative syntax framework to the contemporary Albanian syntax. There are given the basic characteristics of the phrases and how this information stands for the Albanian grammar.

On the one hand the use of the terms "nominal group and verbal group" is also an important positive step in the Albanian syntax (Hyska, 2009) since the word "group" is related to the phrase referring to the form, but on the other hand, still, it does not make clear the hierarchic character of its constituents. The division of the sentence into nominal group and verbal group is not correct because it clearly denies the endocentric character of the sentence. In generative studies the sentence is based on inflection (which bears the characteristics such as tense and person, and it may or may not be realized as separate words in the surface representation of the phrase) and the sentence in itself is an inflectional phrase $(\operatorname{InflP})$.

A significant contribution is given by L. Buxheli. Based on the generative approach she has brought forward the 
books "Models of case marking in contemporary Albanian language" (Modele të caktimit rasor në gjuhën e sotme shqipe) (2007) and "Impersonal verbs in Albanian language" (Foljet njëvetore në gjuhën shqipe) (2011), taking a further positive step in deepening the Albanian syntax into the contemporary trends of modern grammar. It is important to mention the use of the term determinative phrases (DP) instead of noun phrases (NP). The same is found in the second edition of R. Memushaj "Generative linguistics" (Gjuhësia gjenerative) (2008: 153).

Further studies on Albanian generative grammar are taken by Sh. Rrokaj and G. Turano in the article "On the noun phrase of Albanian" (A proposito del sintagma nominale in albanese) (2007: 47-86). In the article the definite and indefinite pronouns are reduced to a single class, the class of determiners, with regard to the generative principles. Furthermore, concerning the studies of pronouns in the frame of generativism there is to be emphasized the book of $R$. Memushaj "The beauty of Albanian language, 2" (Bukuria e gjuhës shqipe, 2) (2008: 154-183). There is distinguished the class of pronouns used as complements and the ones used as head of the phrases.

An important contribution is given by the translation of the Italian generativist G. Graffi into Albanian by B. Topalli in the book "Syntax - the structures of speech" (1994) and the book "What is generative grammar" translated by R. Memushaj (2008).

Research is mainly taken by the Institute of Linguistics and Literature, the department of Linguistics in the University of Tirana and Gjirokastra.

\section{Language Acquisition and Pragmatics in Albanian Grammar}

According to MacWhinney (2001: 467) given the pervasiveness and inevitability of first language acquisition, we often tend to take the process of language learning for granted. But language is the most complex skill that a human being can master. Furthermore, he adds that the fact that nearly all of us succeed in this task indicates how remarkably well the structure of language adapts to our underlying abilities. Language is immensely complex, but its complexity is accessible to all of us.

In generative grammar, language acquisition is related to Chomsky's Universal Grammar (UG). Radford (2004: 6) states that in contrast to the taxonomic approach adopted in traditional grammar, Chomsky takes a cognitive approach to the study of grammar. For Chomsky, the goal of the linguist is to determine what it is that native speakers know about their native language which enables them to speak and understand the language: hence, the study of language is part of the wider study of cognition (i.e. what human beings know).

As Haegeman, (1998: 15) puts it the mastery of a language is not really the result of learning. Rather, being equipped with UG (with its parameters) and exposed to a language, the child cannot but construct the grammar of the language he is exposed to. For this reason the term 'learning' is often replaced by the term "acquisition".

Concerning language acquisition and pragmatics in Albanian grammar - to my knowledge - a step forward is taken by E. Kapia (2013: 179-190), focusing her research in the field of first language acquisition with regard to bilingual first language acquisition in the article "Assessing narrative development in bilingual first language acquisition" (among other works). According to the author there is done research in monolingual children and bilingual children which show different developmental paths depending on whether micro structure or macro structure language elements are considered.

Nevertheless, there are gaps to be filled in Albanian generative grammar which requires time, serious commitment and in depth research by the new generation of generativists who need to apply into Albanian the universal rules and principles of generativism.

\section{Concluding Remarks}

This is an entry-level introduction to generative approach of Albanian grammar based on the three aspects of generativism - what constitutes the knowledge of language, how the knowledge is acquired and how the knowledge is put to use. Most part of the Albanian generativists' research is mainly focused on the phrase and phrase structure in general. As a result it is the main element adopted in the syntactic analyses with regard to Albanian generative syntax. The structural analysis using the phrase is an all inclusive analysis which challenges the traditional analysis of word grouping. Research is done in language acquisition as well (with regard to acquiring of Albanian language), which in a way or another fulfills the three aspects of generativism. It is also a necessity for Albanian grammar to follow the contemporary approaches in grammar and walk on the same paths and trends beside the modern grammar. 


\section{References}

Ahmetaj, S. (2001). Seminar Ndërkombëtar për gjuhën, letërsinë dhe kulturën shqiptare. Prishtinë, pp. 415

Ahmetaj, S. (2000). Gjymtyrimi i fjalisë, In "Gjuha shqipe 1-2", Instituti Albanologjik i Prishtinës, Prishtinë, pp. 5

Buxheli, L. (2007). Modelet e caktimit rasor në gjuhën e sotme shqipe, Nereida, Tiranë

Buxheli, L. (2011). Foljet njëvetore në gjuhën e sotme shqipe, Qendra e Studimeve Albanologjike, Instituti i Gjuhësisë dhe i Letërsisë, Tirana

Dhima, Th. (2005). Gjuha Shqipe Sintaksa, ShBLU, Tiranë

Graffi, G. (2008). Ç'është gramatika gjenerative, Botimet Toena

Graffi, G. (1994). Sintassi, il Mulino

Gramatika e gjuhës shqipe (2002). Akademia e Shkencave e Shqipërisë, Instituti i Gjuhësisë dhe Letërsisë, Vëllimi I - Morfologjia, Tiranë

Gramatika e Gjuhës Shqipe (2002). Akademia e Shkencave e Shqipërisë, Instituti i Gjuhësisë dhe Letërsisë, Vëllimi II - Sintaksa, Tiranë Haegeman, L. (1998). Introduction to Government and Binding Theory, Second Edition, Blackwell Publishers Ltd.

Hubbard, Philip L. (1981). Dative Clitics in Albanian: Evidence for Syntactic Levels. In Proceedings of the Seventh Annual Meeting of the Berkeley Linguistics Society pp. 82-92

Hyska, H. (2009). Sintagma Emërore në Gjuhën Shqipe, Master Thesis, Faculty of History and Philology, Department of Albanian Language, Tirana

Kallulli, D. (1995). Clitics in Albanian, In "Working Papers in Linguistics", University of Trondheim

Kallulli, D. (1999). The Comparative Syntax of Albanian: On the Contribution of Syntactic Types to Propositional Interpretetion, pp. 11

Kallulli, D. (2001). Direct Object Clitic Doubling in Albanian and Greek. In Comparative Syntax of Balkan Languages Edited by Maria Luisa Rivero, Angela Ralli, Oxford University Press

Kapia, E. (2013). Assessing narrative development in bilingual first language acquisition. In Linguistic Superdiversity in Urban Areas: Research approaches, Duarte, Joana and Ingrid Gogolin (eds.), pp. 179-190

Koleci, F. Turano, G. (2011). Hyrje në Sintaksën Gjenerative të Shqipes, Shtëpia Botuese e Librit Universitar, Tiranë

MacWhinney, B. (2001). First Language Acquisition In The Handbook of Linguistics, Mark Aronoff, Janie Rees-Miller, Blackwell Publishers Ltd.

Memushaj, R. (2002). Hyrje në gjuhësi, Dituria, Tiranë, pp. 262-263

Memushaj, R. (2008). Gjuhësia gjenerative, SHBLU, Tiranë, pp. 153

Memushaj, R. (2008). Bukuria e gjuhës shqipe, 2, Enti i Teksteve dhe i Mjeteve Mësimore, Podgoricë, pp. 154-183

Mita, J. (2005). Hyrje në sintaksën gjenerative, Shpresa, Prishtinë, pp. 30

Prifti, S. (1957). Sintaksa, Tiranë, pp. 20-21

Radford, A. (2004). Minimalist Syntax Exploring the Structure of English, Cambridge University Press

Turano,G. and Rrokaj, Sh. (2007). A proposito del sintagma nominale in albanese, In Sh. Rrokaj "Çështje të gjuhës shqipe", pp. 47-86

Wasow, Th. (2001). Generative Grammar. In The Handbook of Linguistics, Mark Aronoff, Janie Rees-Miller, Blackwell Publishers Ltd. 